\title{
Prostate Cancer Pathologic Primary Tumor TNM Finding v8
}

National Cancer Institute

\section{Source}

National Cancer Institute. Prostate Cancer Pathologic Primary Tumor TNM Finding v8. NCI Thesaurus. Code C140151.

A pathologic finding about one or more characteristics of prostate cancer, following the rules of the TNM AJCC V8 classification system as they pertain to staging of the primary tumor. There is no pathologic T1 classification. 